\title{
Poverty Profile and Poverty Measurement Technique of Nepal
}

\author{
Nand Kishor Kumar ${ }^{1}$
}

\begin{abstract}
Poverty measurement is necessary for making anti-poverty policy and social spending policy in a rapidly changing economic environment. Cost of basic needs (CBN) method is the widely used in Nepal for measuring poverty line. The main objective of this paper is to evaluate the poverty profile of Nepal and to assess the practices of poverty measurement of Central Bureau of Statistics in Nepal. This study has employed descriptive method of analysis. The major conclusion of this study is that the poverty situation of the Nepal is declining. It also suggests that during the evaluation of poverty line in every survey, the new poverty line should incorporate calorie requirement for changing lifestyle and taste of human's increasing wants.
\end{abstract}

Key words: Poverty Line, Calorie Requirement, Poverty Measurement Indicator.

\section{INTRODUCTION}

Poverty, in the simplest term, is not having enough money to meet basic needs including food, clothing and shelter. It is a complex social issue requiring multidimensional intervention from more than one institution - the family, the nation, and international agencies. In spite of vigorous efforts from these institutions, it still remains a great challenge to all of them. The challenge lies not only limited to alleviating from the state of poverty, but also on defining and measuring the poverty itself.

The main indicator of income-based poverty is the percentage of people living below poverty line (NPC, 2005). Using data from living standard surveys, monetary values of consumption expenditure on multiple aspects of life, including food, education, housing and assets, were calculated for surveyed households and compared against poverty line below which individuals were deemed poor. Poverty lines were estimated based on the Cost of Basic Needs (CBN) approach (Ravallion, 1994, 1998) and tied to the minimum amount of Nepali rupees needed to satisfy caloric requirements and basic needs for non-food goods and services.

1. Mr. Kumar is Lecturer at Tribhuvan University, Faculty of Humanities, Tri-Chandra Campus. He can be reached at namanmuskan57@gmail.com 
The government of Nepal introduced the basic needs approach to development planning since late 1970's (NPC, 1985-90). Rationale behind using the approach was to overcome the inability of implementation of various development plans to ensure minimum quality of life for the people. The seventh five-year development plan (1986-90) identified bundle of basic needs - food, clothing, fuel, wood, drinking water, peace and security, and minimum road transportation facilities.

Nepal started constructing poverty line using the cost of basic needs (CBN) method from 1995-96 (NLSS-I) onwards. The estimation of poverty in NLSS-II (2003/04) and III (2011) were based on the same methodology applied in the NLSS-I. According to the cost of basic need approach, the poverty line is defined as the expenditure value (in local currency) required by an individual to fulfill her/his basic needs in terms of both food and non-foods items.

The poverty line for the 2003-04 survey (NLSS II) was an update of prices for the same basic needs basket estimated for the 1995-96 (NLSS I). In case of 2010-11 (NLSS-III), the poverty line was estimated based on a new basic needs basket of the poor to reflect changes in well-being over time (CBS, 2011a). The overall poverty line in Nepal is being obtained by aggregating the food and non-food poverty line. The food basket of the poverty line is constructed by estimating how much the poor spends to maintain a minimum caloric requirement of $2,220 \mathrm{kcal}$ per day. The main objective of the study is to evaluate the poverty profile of Nepal and assess the poverty measurement practice of Central Bureau of Statistics in Nepal.

In the remaining sections of this paper are organized as follows. Section II is literature review, section III describes the research method and section IV describes the data analysis, and section $\mathrm{V}$ provides the conclusions of the study.

\section{LITERATURE REVIEW}

Ravallion and Bidani (1994) stated that a poverty line separates the population into those who have an adequate level of welfare from those who do not. Poverty line can thus be interpreted as deflator that establishes the welfare comparability of nominal expenditure (or income) across the poverty profile. World Bank (2011) recommends using objective, absolute poverty lines in developing countries and suggested to conduct sensitivity analysis and build consensus.

Chhetry (2004) reviewed the poverty measuring practices, available measures of poverty and economic growth figures of Nepal. This study stated that the currently available three poverty rates for fiscal years 1976/77, 1984/85 and 1995/96 were not comparable mainly due to change in methodology overtime. Despite such methodology the three poverty rates average round 40 percent. The study suggested weak linkage between macro and micro economic development. UNDP (2015) reported that Nepal has made successful strides in reducing poverty from 25.2 percent in 2011 to 21.6 percent in 2015; however, these numbers belie a harsh reality: huge disparity and inequality persist between region and social groups. 
World Bank (2018) reported that strong progress had been made over the last two decades on reducing poverty and boosting shared prosperity. It further stated that the proportion of Nepalese households living in poverty as measured by the international extreme poverty line fell from 46 percent in 1996 to 25 percent in 2011. A similarly impressive improvement in well-being is observed when national poverty line is considered. The national poverty rate was 25 percent in 2011 , and gains in other dimensions of welfare are also evident. It also stated that Nepal's population is ethnically diverse. It is mixed geographically, with few areas where any ethnic group or caste has a majority. According to the Word Bank (2018), poverty headcount ratio at a higher line (US $\$ 3.20$ per person a day for Nepal) was 41 percent in 2018, 10 percentage point decrease from 2010. Despite the declining poverty trend, vulnerability remains high in Nepal. In this background, this paper attempts to analyze the current situation of poverty in Nepal and assesses the poverty measurement techniques applied by CBS.

\section{RESEARCH METHOD AND DATA SOURCES}

The study has employed descriptive method of analysis. The study is mainly based on secondary data published by various sources - Central Bureau of Statistics, National Planning Commission of Nepal, Nepal Rastra Bank, and the World Bank. Primarily, the analysis has been made on the data collected from Nepal Living Standard Survey (NLSS-I, 1995/96; NLSS-II, 2003/04; and NLSS-III, 2010/11) conducted by Central Bureau of Statistics at various dates. At this point, it is important to note that the data were collected by different agencies at different point of time using different methodology, one should be aware of making direct comparison.

\section{DATA ANALYSIS AND FINDING}

This section analyzes the trend of poverty and measurements of poverty in Nepal.

\section{Trend of Poverty in Nepal}

The trend of incidence of poverty in Nepal covering a period from 1997 to 2011 has been presented in Table 1. It can be seen from the table that it was 36.20 percent in 1977, which increased to 42.50 percent in 1985 . Then it declined to 40 percent as per WB/UNDP survey in 1989 and further increased to 41.80 percent as per CBS-NLSS-I in 1995/96. As stated in the methodology, the fluctuation could be due to the definition, measurement, and survey methodology followed by the surveying agencies. Since 1995/96 onwards, the data used were taken from the same source (NLSS) which has used consistent methodology of poverty definition and measurement. Therefore, further analysis has been done based on the data covered by NLSS surveys.

The incidence of poverty between 1995/96 - 2010/11 has declined significantly from 41.80 percent to 25.20 percent at national level. But when the national data is further looked at from rural-urban perspective it gives different perspective. The 
incidence of poverty is higher in rural area than in urban area in all three surveys (NLSS-I, NLSS-II, and NLSS-III). But interestingly, rate of decline is different. The rural poverty index has consistently declined from 43.30 in 1995/96 to 34.60 in $2003 / 04$ to 27.40 in $2010 / 11$. The urban index has also declined from 21.60 to 9.60 between 1995/96 and 2003/04, but it has increased to 15.60 in 2010/11.

Table 1

Trends of Poverty in Nepal (Estimated as Head Count Index, 1977-2011)

\begin{tabular}{lllll}
\hline \multirow{2}{*}{ Years of Estimate } & Source & \multicolumn{3}{c}{ Incidence of poverty \% } \\
\cline { 3 - 5 } & & Rural & Urban & National \\
\hline 1977 & NPC & 37.20 & 17.06 & 36.20 \\
1985 & MPHBS/NRB & 43.20 & 19.20 & 42.50 \\
1989 & WB/UNDP & 42.00 & 15.00 & 40.00 \\
$1995 / 96$ & CBS-NLSS-I & 43.30 & 21.60 & 41.80 \\
$2003 / 04$ & CBS-NLSS-II & 34.60 & 9.60 & 30.90 \\
$2010 / 11$ & CBS-NLSS-III & 27.40 & 15.50 & 25.20 \\
\hline
\end{tabular}

* The minimum calorie requirement as perspire was $2256 \mathrm{kcals}$

Source : NSAC, 1998: CBS, 2005 \& 2011a

Figure 1 shows changes in poverty over time using the old 1995-96 poverty line (approach 1) and changes based on the "new", more generous 2010-11 poverty line (CB, 2011).

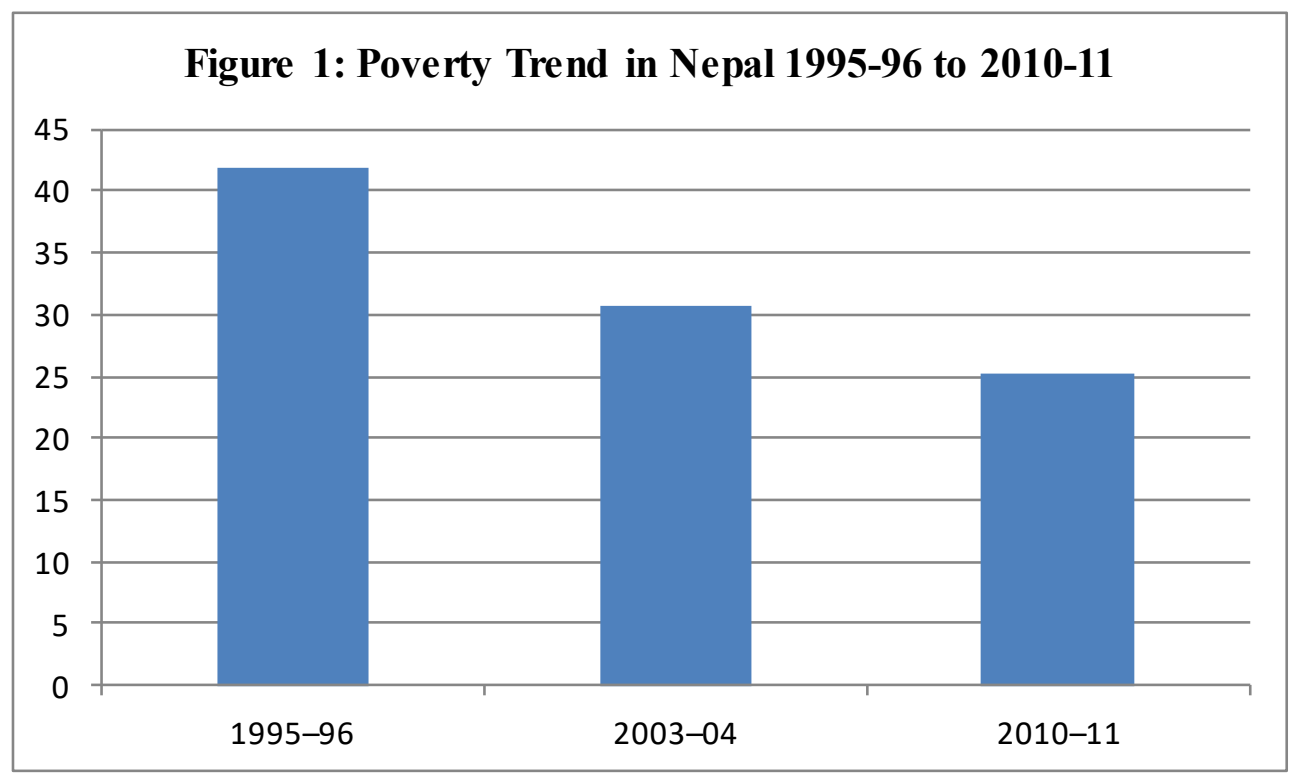

\section{Poverty Measurement}

Table 2 presents poverty in 2010/11 with 1995/96 and 2003/04 in terms of (i) poverty headcount index, (ii) poverty gap index, and (iii) squared poverty gap index. The poverty 
headcount index (ratio) is the percentage of the population living below the national poverty lines ${ }^{1}$. The poverty gap index is a measure of the intensity of poverty. It is defined as the average poverty gap in the population as a proportion of the poverty line. Poverty gap index estimates the depth of poverty by considering how far, on the average, the poor are from that poverty line. Squared poverty gap index, also known poverty severity index, is related to poverty gap index. It is calculated by averaging the square of the poverty gap ratio. By squaring each poverty gap data, the measure puts more weight the further a poor person's observed income falls below the poverty line.

Table 2

Poverty Measurement, 1995/96-2009/10

\begin{tabular}{|c|c|c|c|c|c|c|c|c|c|}
\hline & \multicolumn{3}{|c|}{ Poverty headcount index } & \multicolumn{3}{|c|}{ Poverty gap index } & \multicolumn{3}{|c|}{ Squared poverty gap index } \\
\hline & $1995 / 96$ & $2003 / 04$ & $2010 / 11$ & $1995 / 96$ & $2003 / 04$ & 2010/11 & $1995 / 96$ & $2003 / 04$ & $2010 / 11$ \\
\hline Nepal & 41.76 & 30.85 & 25.16 & 11.75 & 7.60 & 7.543 & 4.67 & 2.70 & 1.81 \\
\hline Urban & 21.56 & 9.55 & 15.46 & 6.54 & 2.20 & 3.19 & 2.65 & 0.70 & 1.01 \\
\hline Rural & 43.27 & 24.62 & 27.43 & 12.14 & 8.50 & 5.96 & 4.83 & 3.10 & 2.00 \\
\hline
\end{tabular}

Source. CBS (2011a)

The poverty headcount ratio has declined by approximately 30 percent during the period (1995/96 - 2010/11). This overcrowding of poverty incidence to the rural area seems started to shift to the urban area for the latest period of observation. The poverty gap index also exhibits similar trend, but squared poverty gap index has more significant decline over the period. They indicate that the intensity of poverty has also declined significantly.

\section{DISCUSSION AND CONCLUSION}

According to NPC, expenditure on minimum food requirement covers only 65 percent of subsistence consumption expenditure goes on food, the remaining 35 percent of subsistence consumption expenditure on non-food items. This approach is silent about determination of an adequate set of non-food item (for which there is objective standard than the nutritional requirements in the case of food), it may give rise to strong disagreements on the appropriate list, as well as the difficulty to current pricing them. This approach is less sensitive about non-monetary indicators of poverty, poverty has been traditionally measured in monetary terms, and it has many other dimensions. Poverty is associated not only with insufficient income or consumption but also with insufficient outcomes with respect to health, nutrition and literacy and with deficient social relations,

1. According to CBN approach the poverty line can be defined as the expenditure value (in local currency) required by an individual to fulfil his/her basic needs in terms of both food and non-food items. While the poverty line in the previous round for the survey in 2003-04 (NLSS-II) was an update of prices for same basic needs basket estimated in 1995-96 (NLSS-I), the poverty line for 2010-11 is based on new basic basket of the poor to reflect changes in wellbeing over time. 
78 I PYC Nepal Journal of Management, August 2019, Vol. XII, No. 1

insecurity and low self-esteem and powerlessness. Therefore, the measurement of poverty should consider the following as well:

a. This approach measure poverty at household level, do not measure at individual level. Poverty measured at household level assumes that everyone in a poor household is poor. But there could be inequality within household, - probably people are living in poverty in non-poor households and non-poor individual is living in poor households.

b. This approach also neglects poverty risk factors. Serious diseases increase poverty. Children and women face such type of poverty risk. Such risk may vary with geographical variation.

c. This approach tells about poverty rate but does not measure the depth of individuals' economic need and increasing wants. Similarly, it is not linked with GDP of nation, though poverty alleviation in interlinked with the growth of GDP.

\section{REFERENCES}

CBS. (1995-96). Nepal living standard survey. Kathmandu: Center Bureu of Statistics.

CBS. (2003/04). Nepal living standard survey. Kathmandu: Central Bureau of Statistics.

CBS. (2005). Poverty trends in Nepal. Kathmandu: Center Bureu of Statistics.

CBS. (2010/11). Nepal living standard survey. Kathmandu: Central Bureau of Statistics.

CBS. (2003-04). Nepal living standard survey. Kathmandu: Center Bureu of Statistics

Chhetry, D. (2004). Practices of poverty measurement and poverty profile of Nepal. Kathmandu:

Asian Development Bank, EDR working paper series No. 57

HMG (1994). Survey Buttetin, Kathmandu: HMG, Ministry of Agriculture.

Hutto, N., Waldfogen, J. \& Kaushal, N. (2001). Improving measure of poverty. Social Science Review. 85(1), 39-79.

NPC. (1985-90). Approach to the $7^{\text {th }}$ Plan. Kathmandu: HMG/N.NPC.

Ravallion, M. \& Bidani, B. (1994). How robust is a poverty profile? The World Bank Economic Review 8(1), Pp. 75-102.

Ravallion, M. (1998). Poverty line in theory and practices. Washington: Living standard measurement study working paper, LSM 133, World Bank.

UNDP(2015). Human Development Report 2011. Kathmandu: United Nation Development Progream.

World Bank (2011). Poverty measurement: The World Bank approach, Kathmandu: World Bank Nepal.

World Bank (2018). Economic Survey. Kathmandu: World Bank Nepal.

World Bank (2019). The World Bank in Nepal. Washington D.C.: IBRD 